\title{
Pembelajaran Menyimak Naskah Drama Dengan Model Pembelajaran Bermain Peran Pada Siswa Kelas XI SMK PGRI 3 Bojonegoro
}

\author{
Iva Milatul Chanifah \\ Fakultas ekonomi Universitas Islam Lamongan \\ Email corresponding author: ivamilatul@unisla.ac.id
}

\begin{abstract}
ABSTRAK
Tujuan penelitian adalah untuk mengetahui keefektifan penerapan pembelajaran bermain peran ditinjau berdasarkan aspek yaitu: (1) ketuntasan hasil belajar; dan (2) respon siswa. Penelitian ini merupakan penelitian kualitatif yang bersifat deskriptif dan didukung dengan instrumen penelitian meliputi angket perlakuan siswa, dan tes. Penelitian ini dilakukan dengan satu kali pertemuan atau one shot case today untuk memperoleh hasil yang diinginkan oleh peneliti. Berdasarkan hasil analisis data penelitian ini menunjukkan bahwa dengan menerapkan model pembelajaran bermain peran, memiliki tingkat keefektifan bagi siswa. Dapat dilihat dari perolehan ketuntasan hasil belajar siswa sebesar $63,63 \%$, dan angket perlakuan sebesar $85 \%$ siswa menyetujui pernyataan yang telah tersedia. Kesimpulan penelitian ini yaitu penerapan model pembelajaran bermain peran sangat efektif dalam pembelajaran di dalam kelas bagi guru maupun siswa.
\end{abstract}

Kata Kunci: Pembelajaran Menyimak, Naskah Drama, Bermain Peran

\section{PENDAHULUAN}

Pembelajaran adalah suatu kombinasi yang tersusun meliputi unsur-unsur manusiawi, material, fasilitas, perlengkapan, dan prosedur yang saling mempengaruhi untuk mencapai tujuan pembelajaran. Manusia terlibat dalam sistem pengajaran terdiri dari siswa, guru, dan tenaga lainnya, misalnya tenaga laboratorium. Material meliputi buku-buku, papan tulis, dan kapur, fotografi, slide, dan film, audio dan video tape. Fasilitas dan perlengkapan, terdiri dari ruangan kelas, perlengkapan audio visual, juga komputer. Prosedur, meliputi jadwal dan metode penyampaian informasi, praktik, belajar, ujian dan sebagainya.

Menurut Hamalik (2015:57) menyatakan sistem pembelajaran dapat dilaksanakan dengan cara membaca buku, belajar di kelas atau sekolah, karena diwarnai oleh organisasi dan interaksi antara berbagai komponen yang saling berkaitan, untuk membelajarkan peserta didik. Teori pembelajaran akan menjelaskan bagaimana menimbulkan pengalaman belajar dan bagaimana pula menilai, memperbaiki metode dan teknik yang tepat.

Teori pembelajaran yang demikian itu memungkinkan guru dan peneliti untuk: (1) mengusahakan lingkungan yang optimal untuk belajar, (2) menyusun bahan ajar dan mengurutkannya, (3) memiliki strategi mengajar yang optimal dan apa alasannya, (4) membedakan antara jenis alat yang sifatnya pilihan dan sifatnya essensial untuk membelajarkan para siswa menurut Sugandi dan Haryanto (2007:9). 
Evaluasi pembelajaran merupakan bagian integral dari proses pembelajaran, artinya dalam pembelajaran akan melibatkan tiga aktivitas yaitu perencanaan, pelaksanaan, dan penilaian. Tanpa kegiatan penilaian guru tidak akan tahu bagaimana proses belajar terjadi dan seberapa jauh tujuan pembelajaran itu tercapai menurut Sugandi dan Haryanto (2007:109). Dengan demikian evaluasi mengandung tiga unsur yaitu pengumpulan informasi, penimbangan dengan suatu kriteria dan pengambilan keputusan. Pngambilan evaluasi juga harus sesuai dengan tujuan evaluasi, kegiatan evaluasi harus dilakukan secara sistematis yaitu kegiatan pengukuran, penilaian, dan akhirnya pengambilan keputusan.

Berdasarkan kompetensi dasar 3.16 menganalisis alur cerita, babak demi babak, dan konfliks dalam drama pembelajaran yang sesuai adalah pembelajaran menyimak. Iskandarwassid dan Sunendar (2009:227) menyatakan bahwa menyimak adalah satu bentuk keterampilan berbahasa yang bersifat reseptif. Pada waktu proses pembelajaran, keterampilan ini jelas mendominasi aktivitas siswa dibanding keterampilan lainnya, termasuk keterampilan berbicara. Kegiatan keterampilan menyimak merupakan proses psikomotorik untuk menerima gelombang suara melalui telinga dan mengirimkan pesan yang diterima tersebut ke dalam otak. Namun, proses tersebut hanyalah permulaan dari suatu proses interaktif. Hal ini dibuktikan ketika otak bereaksi terhadap pesan yang telah diterima untuk mengirimkan sejumlah mekanisme kognitif dan afektif yang berbeda.

Dalam praktik pengajaran di sekolah, tentu tidak terlepas dari kegiatan menyimak, karena kegiatan menyimak sudah menjadi suatu bagian dalam dunia pengajaran, terlebih lagi bagi pengajaran bahasa. Namun, kenyataannya keterampilan meyimak siswa masih rendah. Keterampilan menyimak akan dikuasai dengan sendirinya oleh anak didik jika pengajarannya keterampilan berbahasa lainnya sudah berjalan dengan sendirinnya oleh anak didik jika pengajaran keterampilan berbahasa lainnya sudah berjalan dengan baik. Oleh karena itu, dampaknya dalam pengkajian, penelaahan, dan penelitian mengenai keterampilan menyimak siswa masih rendah..

Dalam penerapan pembelajaran menyimak, peneliti menggunakan naskah drama sebagai bahan ajar pada kelas XI SMK PGRI 3 Bojonegoro.Naskah drama adalah barang cetak atau naskah tertulis yang berbentuk dialog, menggambarkan watak seseorang dalam kehidupan, memiliki kesatuan dan berfungsi sebagai naskah sastra (untuk dibaca) maupun sebagai naskah untuk dipentaskan. Sebagaimana telah disebutkan ada karya drama yang memang tepat dan cocok untuk dipentaskan, tetapi tidak sedikit pula hanya sesuai untuk dibaca sendiri seperti sebuah novel atau prosa lainya. Kelayakan atau kekuranglayakan sebuah naskah untuk dipentaskan, bukan saja karena bentuk penulisanya yang seperti prosa, tetapi juga dapat terjadi pada karya drama yang secara fisik telah memenuhi kriteria sebuah karya drama (Budianto, 2006:111). 
Pembelajaran menyimak naskah drama pada kompetensi dasar 4.16 yaitu mempertunjukkan salah satu tokoh dalam drama yang dibaca atau ditonton secara lisan peneliti menggunakan model pembelajaran bermain peran yang sangat sesuai dengan indikator pencapaian kompetensi yang telah ditentukan. Model ini, pertama dibuat berdasarkan asumsi bahwa sangatlah mungkin menciptakan analogi otentik ke dalam suatu situasi permasalahan kehidupan nyata. Kedua, bahwa bermain peran dapat mendorong siswa mengekspresikan perasaannya dan bahkan melepaskan. Ketiga bahwa proses psikologis melibatkan sikap, nilai, dan keyakinan kita sera mengarahkan pada kesadaran melalui keterlibatan spontan yang disertai analisis.

Dalam kehidupan nyata, setiap orang mempunyai cara unik dalam berhubungan dengan orang lain. Masing-masing dalam kehidupan memainkan sesuatu yang dinamakan peran. Oleh karena itu, untuk dapat memahami diri sendiri dan orang lain sangatlah penting bagi kita untuk menyadari peran dan bagaimana peran tersebut dilakukan. Untuk kebutuhan ini, kita mampu menempatkan diri dalam posisi atau situasi orang lain dan mengalami atau mendalami sebanyak mungkin pikiran dan perasaan orang lain tersebut. Kemampuan ini adalah kunci bagi setiap individu untuk dapat memahami dirinya dan orang lain yang pada akhirnya dapat berhubungan dengan orang lain.

Menurut Uno (2014:26) bermain peran adalah suatu model pembelajaran yang bertujuan untuk membantu siswa menemukan makna diri di dunia sosial dan memecahkan dilema dengan bantuan kelompok. Artinya, melalui bermain peran siswa belajar menggunakan konsep peran menyadari adanya peran-peran berbeda dan memikirkan perilaku dirinya dan perilaku orang lain. Proses bermain peran ini dapat memberikan contoh kehidupan perilaku manusia yang berguna sebagai sarana bagi siswa untuk: (1) menggali perasaannya; (2) memperoleh inspirasi dan pemahaman yang berpengaruh terhadap sikap, nilai, dan persepsinya; (3) mengembangkan keterampilan dan sikap dalam emmecahkan masalah; dan (4) mendalami mata pelajaran dengan berbagai macam cara. Hal ini akan bermanfaat bagi siswa pada saat terjun ke masyarakat kelas karena ia akan mendapatkan diri dalam suatu situasi di mana begitu banyak peran terjadi, seperti dalam lingkungan keluarga, bertetangga, lingkungan kerja, dan lain-lain.

Keefektifan penerapan model pembelajaran bermain peran menggunakan naskah drama pada siswa kelas XI SMK 3 PGRI akan dievaluasi baik yang berfungsi formatif maupun sumatif adalah tahap pengumpulan informasi melalui pengukuran. Pengumpulan informasi hasil belajar itu dapat ditempuh melalui dua cara yaitu dengan testing dan nontesting. Tes hasil belajar adalah alat untuk mengukur kemampuan berfikir, sedangkan teknik non tes lebih banyak digunakan untuk mengungkap kemampuan psikomotorik dan hasil belajar afektif. Empat macam teknik yang digunakan dalam evaluasi hasil pembelajaran meliputi: (1) tes ketuntasan hasil belajar; dan (2) angket perlakuan siswa. 
Keefektifan model pembelajaran bermain peran ditinjau berdasarkan tes ketuntasan hasil belajar siswa merupakan proses untuk menentukan nilai belajar siswa melalui kegiatan penilaian dan atau pengukuran hasil belajar. Mudjiono dan Dimyati (2015:200) menyatakan bahwa tujuan utama evaluasi hasil belajar dapat menengarai tujuan utamanya adalah untuk mengetahui tingkat keberhasilan yang dicapai oleh siswa setelah mengikuti suatu kegiatan pembelajaran, di mana tingkat keberhasilan tersebut ditandai dengan skala nilai berupa huruf atau kata atau simbol.

Efektifitas model pembelajaran bermain peran ditinjau berdasarkan angket perlakuan siswa dapat diperoleh berbagai informasi tentang kualitas program pembelajaran dengan berakhirnya seluruh rangkaian proses pembelajaran yang diukur dengan menggunakan angket perlakuan siswa.

Berdasarkan hasil penjelasan di atas, perlu adanya inovasi baru dalam pembelajaran di dalam kelas agar siswa dapat menerima materi yang telah diberikan oleh guru. Salah satunya adalah dengan menerapkan model pembelajaran yang menarik dan dapat membangkitkan semangat belajar siswa.

Model pembelajaran tersebut harus sesuai dengan kompetensi dasar yang akan diajarkan kepada siswa. Oleh karena itu, model pembelajaran yang sesuai dengan kompetensi dasar adalah model pembelajaran bermain peran.Melalui model pembelajaran bermain peran, siswa dapat meningkatkan kemampuan untuk mengenal perasaannya sendiri dan perasaan orang lain. Mereka memperoleh cara berperilaku baru untuk mengatasi masalah seperti dalam permainan perannya dan dapat meningkatkan keterampilan memecahkan masalah. Berdasarkan penjabaran tersebut, peneliti melakukan penelitian kualitatif yang bersifat deskriptif yang berjudul pembelajaran menyimak naskah drama dengan model pembelajaran bermain peran pada siswa kelas XI SMK PGRI 3 Bojonegoro.

\section{METODE PENELITIAN}

Penelitian tentang pembelajaran menyimak naskah drama dengan model pembelajaran bermain peran p9ada siswa kelas XI SMK PGRI 3 Bojonegoro menggunakan metode kualitatif yang bersifat deskriptif. Menurut Sukardi (2018:157) penelitian deskriptif merupakan metode penelitian yang berusaha menggambarkan dan menginterpretasi objek sesuai dengan apa adanya. Penelitian ini juga sering disebut non eksperimen, karena pada penelitian ini peneliti tidak melakukan kontrol. Disamping itu, penelitian deskriptif juga merupakan penelitian, dimana pengumpulan data untuk mengetes pertanyaan penelitian atau hipotesis yang berkaitan dengan keadaan dan kejadian sekarang. Mereka melaporkan keadaan objek atau subjek yang diteliti sesuai apa adanya. Penelitian ini menafsirkan dan menguraikan data yang bersangkutan dengan situasi yang sedang terjadi, sikap serta pandangan yang terjadi di dalam suatu masyarakat, pertentangan antara dua 
keadaan atau lebih, hubungan antar variabel yang timbul, perbedaan antar fakta yang ada serta pengaruhnya terhadap suatu kondisi, dan sebagainya.

Penelitian ini mendeskripsikan evaluasi penerapan model pembelajaran bermain peran dapat meningkatkan keefektifan dalam pembelajaran yang ditinjau dari segi ketuntasan hasil belajar, respon siswa, respon guru, aktivitas siswa, dan aktivitas guru. Pengambilan data awal dan akhir yaitu nilai tes ketuntasan hasil belajar, angket perlakuan respon siswa, wawancara respon guru, observasi aktivitas siswa, dan observasi aktivitas guru dilakukan dalam beberapa tahap, yaitu: (1) mengajukan perijinan ke sekolah; (2) pembuatan studi bahasa Indonesia guna menjelaskan rencana penelitian dilanjutkan dengan pembekalan mengenai penerapan model pembelajaran bermain peran bagi guru pelaksana; (3) mengembangkan strategi pembelajaran bersama dengan guru mata pelajaran dan dosen pembimbing; (4) melaksanakan pembelajaran dengan menerapkan model pembelajaran bermain peran; (5) melaksanakan tes ketuntasan hasil belajar siswa. Dalam pertemuan koordinasi dengan guru mata pelajaran bahasa Indonesia, peneliti menyampaikan rancangan penelitian dan membuat kesepakatan dengan guru mengenai materi pembelajaran yang akan disampaikan selama penelitian. Materi tersebut ditentukan berdasar perangkat pembelajaran standar isi pada kurikulum 2013.

Kesepakatan materi tersebut adalah pembelajaran menyimak naskah drama pada kompetensi dasar menganalisis alur cerita, babak demi babak, dan konfliks dalam drama yang dibaca atau ditonton; mempertunjukkan salah satu tokoh dalam drama yang dibaca atau ditonton secara lisan. Berdasarkan kesepakatan dengan guru, peneliti menyusun satu RPP (Rencana Pelaksanaan Pembelajaran) serta menyiapkan naskah drama serta tes ketuntasan hasil belajar siswa. Penerapan model pembelajaran bermain peran di kelas diikuti dengan pemberian aktivitas dan penugasan-penugasan pada siswa, yakni dengan pelaksanaan bermain peran dan pengerjaan tes ketuntasan hasil belajar siswa yang diberikan untuk melatih kemampuan dan pemahaman siswa mengenai alur; babak demi babak; konfliks dan watak dari peran yang telah disajikan oleh teman-teman yang melakukan pementasan drama di depan kelas. Materi yang diberikan pada kelas adalah pengertian drama; jenis drama; unsur-unsur drama; struktur drama; babak dalam drama; langkah memunculkan konfliks dalam drama; dimensi tokoh; pembagian tokoh; kru dalam pementasan drama; langkah-langkah mendemonstrasikan drama; serta satu naskah drama yang bertemakan persahabatan. Penelitian ini menggunakan desain studi kasus sekali test (one shot case today). Menurut Arifin (2012:129) desain jenis ini termasuk dalam jenis desain pre-eksperimen. Pada jenis ini tidak terdapat kelompok kontrol. Tetapi hanya satu kelompok yang diukur dan diamati gejala-gejala yang muncul setelah diberi perlakuan. 


\section{TEMUAN DAN PEMBAHASAN}

\section{Keefektifan Penerapan Model Pembelajaran Bermain Peran Ditinjau berdasarkan Ketuntasan Hasil Belajar Siswa dalam Menyimak Naskah Drama}

Evaluasi hasil belajar adalah evaluasi dengan sasaran hasil belajar (Sugandi, 2007:115). Sasaran evaluasi hasil pembelajaran dengan tujuan kognitif meliputi teknik tes menggunakan instrumen tes ketuntasan hasil pembelajaran siswa. Proses penerapan model pembelajaran bermain peran dilaksanakan pada hari Senin, 27 Mei 2019. Kegiatan ini bertujuan untuk melihat ketuntasan hasil belajar siswa. Selain itu, hal ini juga berguna untuk membuktikan kebenaran temuan awal dari hasil wawancara dengan guru. Pelaksanaan kegiatan penerapan model pembelajaran bermain peran dilakukan bersama dengan guru mata pelajaran bahasa Indonesia kelas XI Akuntansi. Guru bertindak sebagai pengajar, sedangkan peneliti sebagai observer. Sementara itu, untuk menilai hasil kerja siswa dilakukan satu kali tes yang terdiri dari tiga soal, yang tiap-tiap soalnya memiliki bobot nilai dua, dengan jumlah keseluruhan bobot nilai tes enam.

Tes didalam kelas dilakukan untuk mengetahui seberapa besar kemampuan yang telah diserap oleh siswa. Pengambilan nilai ketuntasan hasil belajar pada siswa dilakukan dengan cara memberikan penugasan secara individu berupa menjawab soal-soal yang berkaitan dengan alur, babak, dan konfliks secara rinci yang terdapat dalam pementasan drama. Berikut nilai yang didapatkan seluruh siswa yang diperoleh di akhir pembelajaran telah usai.

Tabel 1. Nilai Ketuntasan Hasil Belajar Siswa

\begin{tabular}{ccccc} 
& & & & \\
No. & Nama Siswa & L/P & Nilai & Ketuntasan \\
& & & & \\
\hline $\mathbf{1}$ & Gilang Ramadhan & L & 83,33 & Tuntas \\
\hline $\mathbf{2}$ & Ima Lusiyani & P & 83,33 & Tuntas \\
\hline $\mathbf{3}$ & Luthfi Laili Nur S. R. & P & 50,00 & Belum Tuntas \\
\hline $\mathbf{4}$ & M. Mabrur & L & 83,33 & Tuntas \\
\hline $\mathbf{5}$ & Ratna Nur S. & P & 83,33 & Tuntas \\
\hline $\mathbf{6}$ & Risa Hidayah & P & 50,00 & Belum Tuntas \\
\hline $\mathbf{7}$ & Risma Nur Diantoro & L & 67,77 & Belum Tuntas \\
\hline $\mathbf{8}$ & Rita Cahyani & P & 67,77 & Belum Tuntas \\
\hline $\mathbf{9}$ & Rofiah Dwi & P & 83,33 & Tuntas \\
\hline $\mathbf{1 0}$ & Sulistyoningsih & & & \\
\hline $\mathbf{1 1}$ & Siti Khofifah & P & 83,33 & Tuntas \\
\hline & & P & 83,33 & Tuntas \\
\hline
\end{tabular}


Berdasarkan keseluruhan nilai tes dalam pembelajaran menyimak naskah drama dengan model pembelajaran bermain peran yang diperoleh tujuh dari 11 siswa yang memenuhi nilai standar kelulusan minimal dan empat siswa yang lainnya masih memiliki nilai dibawah rata-rata dalam ketuntasan hasil belajar. Nilai tertinggi di dalam kelas adalah 83,33 yang diperoleh siswa nomor absen 1, 2, 4, 5, 9, 10, dan 11. Sedangkan siswa yang mendapatkan nilai 67,77 adalah nomor absen 7 dan 8 . Siswa nomor absen 3 dan 6mendapatkan niai terendah yaiu 50.00. Berdasarkan nilai yang didapatkan siswa di atas, didapatkan total nilai rata-rata kelas adalah 68,28 yang tidak memenuhi standart kelulusan minimal pada pembelajaran bahasa Indonesia. Presentase ketuntasan hasil belajar siswa adalah 63,63\% dan persentase tidak tuntas sebesar 36,37\%. Standar kelulusan minimal di SMK 3 PGRI Bojonegoro adalah 75,00. Data persentase ketuntasan hasil pembelajaran disajikan dalam diagram berikut.

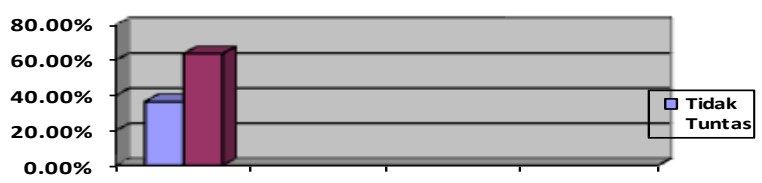

Diagram 1. Ketuntasan Hasil Pembelajaran

Berdasarkan hasil data tersebut, menyatakan bahwa lebih dari 60\% siswa yang mendapat nilai di atas KKM, maka pembelajaran dianggap sangat baik. Hasil pembelajaran menyimak naskah drama dengan model pembelajaran bermain peran pada siswa kelas XI SMK PGRI 3 Bojonegoro dinyatakan berhasil dan siswa mudah menerima materi baik yang disampaikan oleh guru maupun yang disampaikan siswa di kelas melalui model pembelajaran bermain drama atau pementasan drama.

Meskipun persentase ketidaktuntasan siswa sebesar 36,37\%, tetapi siswa tetap menikmati penerapan model pembelajaran bermain peran di kelas karena masih banyak nilai sosial yang didapatkan oleh siswa seperti menyelesaikan atau memecahkan masalah yang ada pada saat persiapan pementasan drama di depan kelas.

Keefektifan Penerapan Model Pembelajaran Bermain Peran Ditinjau berdasarkan Respon Siswa dalam Menyimak Naskah Drama

Evaluasi hasil belajar adalah evaluasi dengan sasaran hasil belajar (Sugandi, 2007:115). Pengumpulan informasi hasil belajar itu dapat diperoleh melalui proses nontes dengan angket perlakuan untuk memperoleh infomasi tentang kualitas penerapan model pembelajaran bermain peran secara menyeluruh yang lebih banyak digunakan untuk mengungkap kemampuan psikomotorik, dan hasil belajar afektif. 
Hasil angket perlakuan untuk mengetahui respon siswa denganpelaksanaan pembelajaran oleh guru pada tanggal Senin, 27 Mei 2019 dapat dilihat pada lembar angket perlakuan penelitian siswa kels XI SMK PGRI 3 Bojonegoro (lampiran empat). Hasil respon siswa dengan pelaksanaan pembelajaran oleh guru difokuskan pada enam pernyataanyakni (1)sebelum ada pembelajaran ini, saya kurang memahami tentang menganalisis naskah drama, (2) saya harus mengetahui secara rinci pengertian drama, jenis-jenis drama, alur drama, unsur-unsur dan struktur drama, (3) saya menjadi tertarik menyimak pementasan drama setelah mengikuti pembelajaran ini, (4),saya mampu menyimak pementasan drama dan menganalisisnya dengan mudah dan baik (5) setelah mengikuti pembelajaran

ini, saya lebih giat menyimakpementasan drama baik secara langsung maupun di televise, dan secara online, dan (6)setelah mengikuti pembelajaran ini, keterampilan saya dalam menyimak pementasan drama semakin meningkat. Setiap pernyataan harus disesuaikan dengan materi yang telah diperoleh tiap-tiap individu siswa.

Pada pernyataan pertama, delapan siswa atau 73\% menyatakan setuju dan tiga siswa atau $27 \%$ menyatakan tidak setuju . Selanjutnya pada pernyataan kedua, Sembilan siswa atau $81 \%$ menyatakan setuju sedangkan dua siswa atau $18 \%$ menyatakan tidak setuju. Pernyataan ketiga, 10 siswa atau 91\% menyatakan setuju, dan satu siswa atau 9\% menyatakan tidak setuju. Pada pernyataan selanjunya, seluruh siswa di kelas setuju 100\% terhadap pernyataan keempat. Sedangkan pada pernyataan kelima dan keenam, Sembilan siswa atau $82 \%$ setuju atas pernyataan tersebut, dan dua siswa atau $18 \%$ tidak menyetujuinya.

Tabel 2. Hasil Angket Perlakuan

\begin{tabular}{|c|c|c|c|c|c|c|c|c|}
\hline No & Nama Siswa & $\mathrm{L} / \mathrm{P}$ & 1 & 2 & 3 & 4 & 5 & 6 \\
\hline 1 & Gilang Ramadhan & $\mathrm{L}$ & $\sqrt{ }$ & - & - & $\sqrt{ }$ & - & $\sqrt{ }$ \\
\hline 2 & Ima Lusiyani & $\mathrm{P}$ & - & $\sqrt{ }$ & $\sqrt{ }$ & $\sqrt{ }$ & $\sqrt{ }$ & $\sqrt{ }$ \\
\hline 3 & Luthfi Laili Nur S. R. & $\mathrm{P}$ & $\sqrt{ }$ & $\sqrt{ }$ & $\sqrt{ }$ & $\sqrt{ }$ & $\sqrt{ }$ & $\sqrt{ }$ \\
\hline 4 & M. Mabrur & $\mathrm{L}$ & $\sqrt{ }$ & $\sqrt{ }$ & $\sqrt{ }$ & $\sqrt{ }$ & - & - \\
\hline 5 & Ratna Nur S. & $\mathrm{P}$ & - & $\sqrt{ }$ & $\sqrt{ }$ & $\sqrt{ }$ & $\sqrt{ }$ & $\sqrt{ }$ \\
\hline 6 & Risa Hidayah & $\mathrm{P}$ & - & - & $\sqrt{ }$ & $\sqrt{ }$ & $\sqrt{ }$ & $\sqrt{ }$ \\
\hline 7 & Risma Nur Diantoro & $\mathrm{L}$ & $\sqrt{ }$ & $\sqrt{ }$ & $\sqrt{ }$ & $\sqrt{ }$ & $\sqrt{ }$ & $\sqrt{ }$ \\
\hline 8 & Rita Cahyani & $\mathrm{P}$ & $\sqrt{ }$ & $\sqrt{ }$ & $\sqrt{ }$ & $\sqrt{ }$ & $\sqrt{ }$ & - \\
\hline 9 & Rofiah Dwi Sulistyoningsih & $\mathrm{P}$ & $\sqrt{ }$ & $\sqrt{ }$ & $\sqrt{ }$ & $\sqrt{ }$ & $\sqrt{ }$ & $\sqrt{ }$ \\
\hline 10 & Siti Khofifah & $\mathrm{P}$ & $\sqrt{ }$ & $\sqrt{ }$ & $\sqrt{ }$ & $\sqrt{ }$ & $\sqrt{ }$ & $\sqrt{ }$ \\
\hline 11 & Siti Faikhotun Nisa & $\mathrm{P}$ & $\sqrt{ }$ & $\sqrt{ }$ & $\sqrt{ }$ & $\sqrt{ }$ & $\sqrt{ }$ & $\sqrt{ }$ \\
\hline \multirow{2}{*}{\multicolumn{2}{|c|}{ Jumlah }} & $\mathrm{Ya}(\sqrt{ })$ & $73 \%$ & $82 \%$ & $91 \%$ & $100 \%$ & $82 \%$ & $82 \%$ \\
\hline & & Tidak(-) & $27 \%$ & $18 \%$ & $9 \%$ & $0 \%$ & $18 \%$ & $18 \%$ \\
\hline
\end{tabular}


Berikut persentase kriteria penilaian yang didapatkan oleh guru berdasarkanenam pernyataan yang telah diterapkan dalam pembelajaran menyimak naskah drama menggunakan model pembelajaran bermain peran.

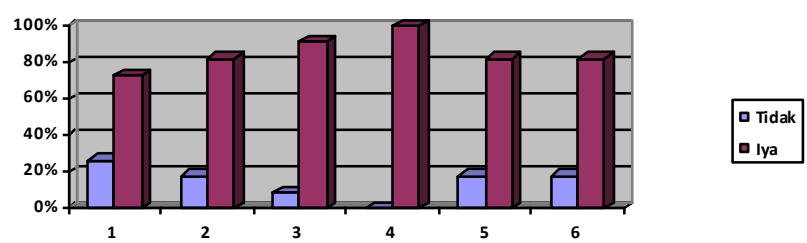

Diagram 2. Hasil Angket Perlakuan

Ditinjau berdasarkan hasil keefektifan model pembelajaran bermain peran keseluruhan respon siswa, 85\% siswa menyatakan iya atau setuju atas penerapan model pembelajaran bermain peran karena telah meningkatkan pemahaman dan pengetahuan siswa mengenai unsur intrinsik naskah drama dan cara menganalisis naskah drama. Tidak sampai disitu, siswa juga menjadi tertarik dengan segala pementasan drama baik secara langsung maupun di televisi bahkan secara online. Siswa juga menyadari akan peningkatan kemampuannya dalam menyimak pementasan drama yang ada.

\section{KESIMPULAN DAN SARAN}

\section{Simpulan}

Berdasarkan hasil analisis data dan pembahasan yang telah diuraikan pada bab-bab sebelumnya, dengan mengacu pada keefektifan penerapan model pembelajaran bermain peran menggunakan naskah drama maka dapat disimpulkan beberapa hal sebagai berikut:

1. Keefektifan model pembelajaran bermain peran ditinjau berdasarkan ketuntasan hasil belajar siswa dalam menyimak naskah drama berdasarkan keseluruhan nilai tes dalam pembelajaran yang diperoleh tujuh dari 11 siswa yang memenuhi nilai standar kelulusan minimal dan empat siswa yang lainnya masih memiliki nilai dibawah rata-rata dalam ketuntasan hasil belajar..Berdasarkan nilai yang diperoleh siswa keseluruhan, total nilai rata-rata kelas adalah 68,28 yang tidak memenuhi standart kelulusan minimal pada pembelajaran bahasa Indonesia. Persentase ketuntasan hasil belajar siswa adalah 63,63\% dan persentase tidak tuntas sebesar 36,37\%. Standar kelulusan minimal di SMK 3 PGRI Bojonegoro adalah 75,00. Jadi dapat disimpulkan bahwa penerapan model pembelajaran bermain peran tidak dapat efektif di dalam pembelajaran kelas XI Akuntansi SMK PGRI 3 Bojonegoro.

2. Keefektifan model pembelajaran bermain peran ditinjau berdasarkan respon siswa dalam menyimak naskah drama dengan menerapkan model pembelajaran bermain peran keseluruhan respon siswa, $85 \%$ siswa menyatakan iya atau setuju 
atas penerapan model pembelajaran bermain peran karena telah meningkatkan pemahaman dan pengetahuan siswa mengenai unsur intrinsik naskah drama dan cara menganalisis naskah drama. Tidak sampai disitu, siswa juga menjadi tertarik dengan segala pementasan drama baik secara langsung maupun di televisi bahkan secara online. Siswa juga menyadari akan peningkatan kemampuannya dalam menyimak pementasan drama yang ada. Jadi, dapat disimpulkan bahwa model pembelajaran bermain peran sangat efektif ditinjau berdasarkan respon siswa.

\section{DAFTAR PUSTAKA}

Arikunto, S. 2010. Prosedur Penelitian: Suatu Pendekatan Praktik. Jakarta: Rineka Cipta Akhadiah, Sabari dkk. 1998. Pembinaan Kemampuan Menulis Bahasa Indonesia.Jakarta: Erlangga.

Anwar Ahmad, 2019. “Pengaruh Model Pembelajaran Kooperatif Tipe Numbered Heads Together berbatuan Media

Baribin, Rahminah. 2005. Teori Apreasiasi Puisi. Semarang IKIP Semarang Press.

Budianto, Melani, dkk. 2006. Membaca Sastra. Magelang: IndonesiaTera.

Djaali. 2007. Psikologi Pendidikan. Jakarta:Bumi Aksara

Djamarah, Zain. 2008. Strategi Belajar Mengajar. Jakarta: Rineka Cipta.

Hamalik, Dr. Oemar. 2015. Kurikulum dan Pembelajaran. Jakarta: PT. Bumi Aksara

Iskandarwassid, dan Sunendar D, (2009). Strategi Pembelajaran Bahasa. Bandung: Rosda

Mudjiono dan Dimyati. 2015. Belajar dan Pembelajaran. Jakarta: Rineka Cipta.

Nurhadi. (1995). Tata Bahasa Pendidikan. Semarang : IKIP Malang Press.

Sugandi, dan Haryanto. 2007. Teori Pembelajaran. Semarang: UPT UNNES PRESS

Sugiyono. 2004. Metode Penelitian. Bandung: Alfabeta

Tarigan, Henry Guntur. 1994. Membaca Sebagai Suatu Keterampilan Berbahasa. Bandung: Angkasa. 